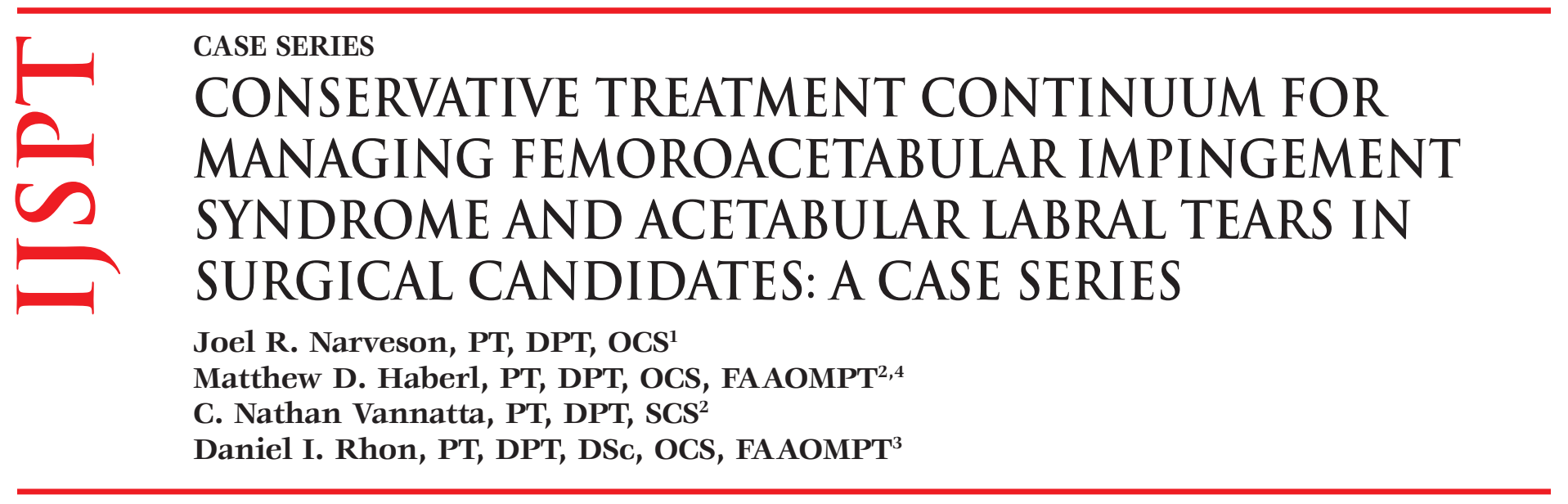

\begin{abstract}
Background/Purpose: Femoroacetabular impingement Syndrome (FAIS) and the often-associated acetabular labral tears (ALTs) are challenging to treat and consensus to guide effective management is lacking. Recent guidelines suggest physical therapy is beneficial, yet the guidance for specific interventions is unclear. The purpose of highlighting these cases was to describe the outcomes and the clinical reasoning process driving conservative management of subjects with FAIS and ALTs that were deemed surgical candidates.
\end{abstract}

\title{
Study Design: Case Series
}

Case Descriptions: Six subjects (20 - 65 years old) with confirmed FAIS and/or ALTs were included. Subjects were assigned to different treatment pathways based on their individual presentation. Three subjects were categorized as having primary mobility impairments and three were categorized with primary neuromuscular control impairments. Treatment intensity was adjusted according to the individual nature of symptoms, and on average lasted 81 days.

Outcomes: Clinically important improvements were seen on all self-reported outcome measures (International Hip Outcome Tool - 33, Numeric Pain Rating Scale, Patient Specific Functional Scale, and Global Rating of Change). At two years, none of the subjects had elected surgical management.

Discussion: These cases illustrate the clinical reasoning process utilized to prioritize subjects' treatment along a continuum of neuromuscular control and mobility. The treatment approach also illustrates successful management of potential surgical candidates that elected to forego surgery after satisfactory completion of conservative management.

Level of Evidence: Level 4

Key Words: Clinical reasoning, femoroacetabular impingement syndrome, hip pain, mobility, neuromuscular control, physical therapy

${ }^{1}$ Creighton University Medical Center, Catholic Health

Initiatives, Omaha, NE, USA

${ }^{2}$ Sports Medicine Physical Therapy, Gundersen Health System,

Onalaska, WI, USA

${ }^{3}$ Assistant Professor, Doctoral Physical Therapy Programs

(DPT and DSc), Baylor University, JBSA Fort Sam Houston,

TX, USA

${ }^{4}$ Residency Director, Specialized Physical Therapy Education,

LLC La Crosse, WI, USA

The authors certify that they have no affiliations with or financial involvement in any organization or entity with a direct financial interest in the subject matter or materials discussed in the article.

CORRESPONDING AUTHOR

Dr. Joel Narveson

7500 Mercy Rd,

Omaha, NE 68124

E-mail: Narveson.joel@gmail.com 


\section{BACKGROUND AND PURPOSE}

Femoroacetabular impingement Syndrome (FAIS) is a movement disorder of the hip resulting in aberrant contact between the femur and acetabulum. ${ }^{1}$ This often co-exists with acetabular labral tears (ALTs), and their clinical presentations continue to challenge healthcare providers. ${ }^{2}$ Evidence for preeminent interventions is lacking and diagnostic criteria remain elusive. ${ }^{1-3}$ This is demonstrated by the average cost to diagnose FAIS (\$2,456 USD) over a typical timeframe of one to three years after hip symptoms first occur. ${ }^{4-6}$ Despite inconclusive evidence for optimal interventions with proven long-term benefit, surgical rates for FAIS are rising. ${ }^{6-13}$ Similarly, evidence is emerging to support successful outcomes with non-surgical management. ${ }^{14-19}$ The majority of studies to date reflect short-term outcomes with little understanding regarding the downstream effects of treatment choices. The goal of treatment for FAIS is to ameliorate symptoms and prevent progression of intra-articular joint disease. .,7-9,15,20 $^{-1}$

Recent guidelines have been published to help optimize management of FAIS and ALTs. ${ }^{1,13,21}$ The guideline authors appropriately recognized that evidence to guide optimal management is lacking, but still recommend a conservative-first approach. Although physical therapy is increasingly being recommended, ${ }^{1,9,13,22}$ guidelines regarding optimal physical therapy interventions remain ambiguous. ${ }^{1,13}$ Various treatment approaches exist, but a clear rationale for treatment selection is lacking. ${ }^{14,17,18}$ The scope of evidence is broad, often contradictory, and varies regarding the importance of range of motion (ROM), strength, neuromuscular control, and functional movement in regard to the development of symptomatic FAIS and ALTs., ${ }^{75,23-28}$ This variability likely represents the wide range of morphological and movement related abnormalities contributing to FAIS and ALTs (Figure 1)..$^{3,29,30}$ This may suggest that a multifarious population exists, amenable to various treatment approaches. ${ }^{14,16-18,22,23,30,31}$ Thus, outcomes are likely optimized when treatment is individualized. This requires thorough clinical examination and sound reasoning in order to guide the treatment plan and is based on addressing neuromuscular control and mobility deficits that align with a proposed treatment process (Table 1). ${ }^{16,20,22,23,32}$ The purpose of highlighting these cases was to describe the outcomes and the clinical reasoning process driving conservative management of subjects with FAIS and ALTs that were deemed surgical candidates.

\section{Clinical Setting, Cohort Selection, and Objective Examination Components}

Surgical candidates between the ages of 18-65 with a diagnosis of FAIS or ALTs were prospectively recruited from a multidisciplinary hospital institution between October of 2014 and December of 2015 (Figure 2). Institutional review board approval was received from Gundersen Clinic, Ltd. (\#2-14-11-001) and subjects provided consent prior to the collection of data. Six subjects from the ages of 20 to 65 agreed to participate in this case series. Diagnosis was confirmed through the presence of: anterior hip or groin pain, symptoms reproduced with hip flexion and FADIR test, positive radiographic signs, and greater than $50 \%$ relief of symptoms after intra-articular injection. ${ }^{1,2}$ Subjects were excluded if their hip symptoms were reproduced with lumbar segmental movement, had pending litigation, were involved in a workmen's compensation case, were pregnant, had prior surgery on the involved hip, were unable to give informed consent or speak, read or write in English, and had already undergone a prior supervised regimen of physical therapy for this condition in the prior six months.

Baseline demographics were recorded (Table 2), and all subjects completed the Medical Screening Questionnaire (MSQ), International Hip Outcome Tool - 33 (IHOT-33), ${ }^{33}$ pain body diagram, ${ }^{34,35}$ Numeric Pain Rating Scale (NPRS), ${ }^{36}$ Patient Specific Functional Scale (PSFS), ${ }^{37}$ and Pain Catastrophizing Scale at baseline (PCS) (Table 3). ${ }^{38,39}$ These outcome measures, with the addition of the Global Rating of Change (GROC), were also reassessed at six weeks or discharge, and six months. ${ }^{40-42}$

An individualized examination and evaluation was performed to determine appropriateness for conservative management, study eligibility, and categorization of patient along a treatment continuum (Table 4). Required examination elements included clearing the lumbar spine (lumbar motion and mobility assessment), ${ }^{43,44}$ sacroiliac provocation tests, ${ }^{45}$ assessment of neurodynamic mobility and functional 

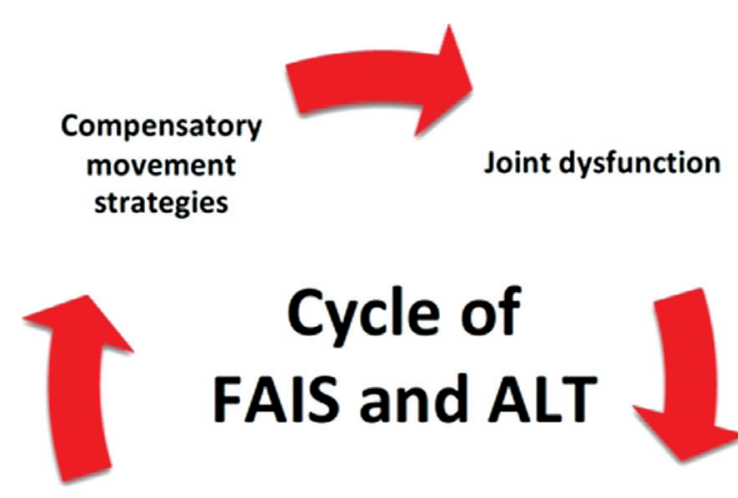

\section{Cycle of FAIS and ALT}
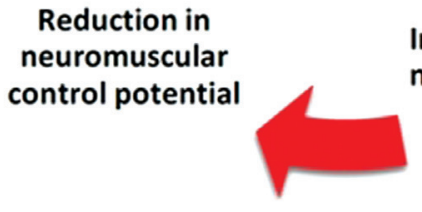
neuromuscular cont
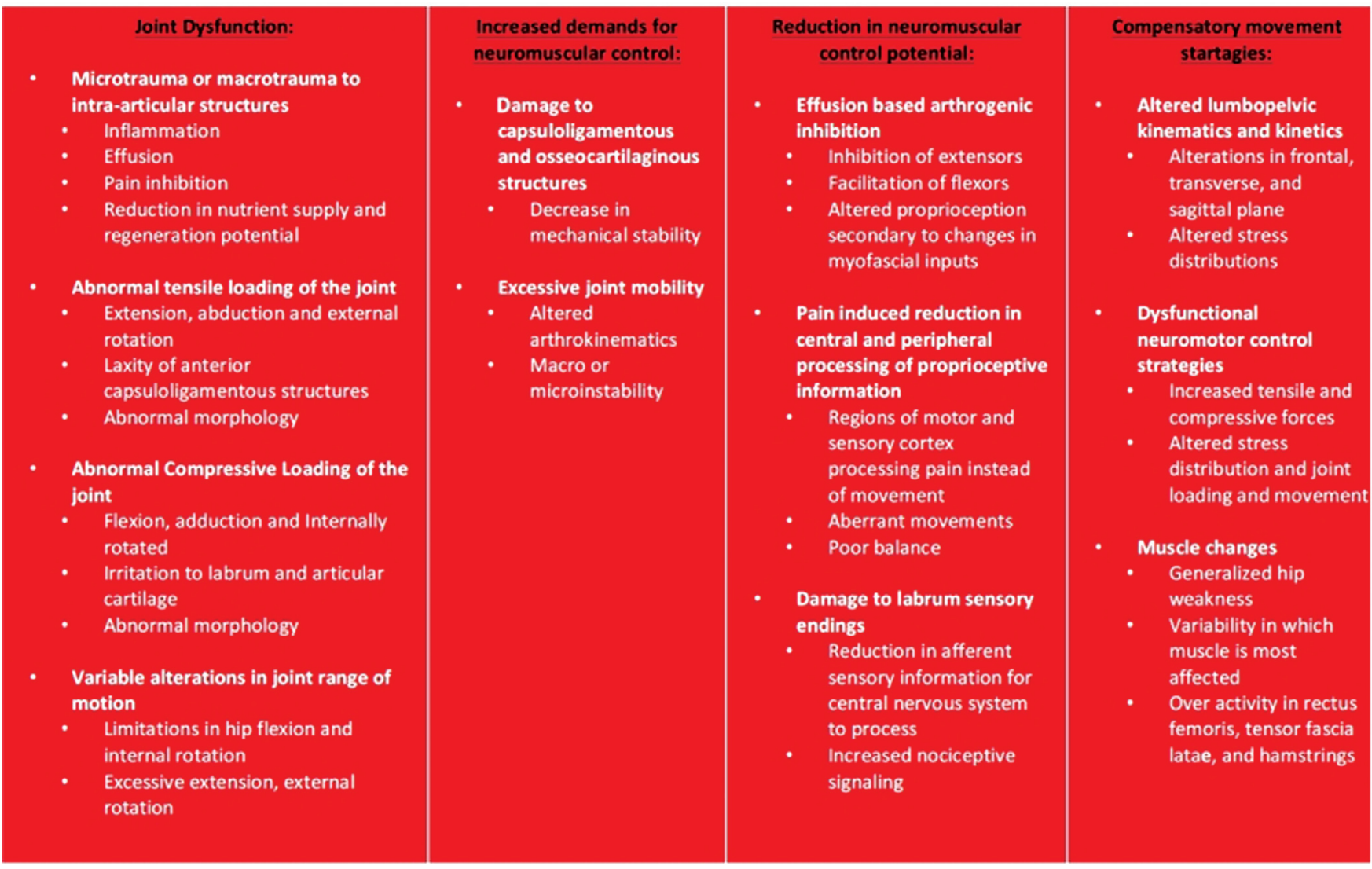

Figure 1. A proposed cycle of FAIS and ALTS

Abbreviations: FAIS - Femoral Acetabular Impingement Syndrome; ALTs - Acetabular Labral Tears

movement screening (multi-segmental flexion, extension, and rotation). ${ }^{46}$ Kinesthetic awareness was assessed with single limb balance tests (eyes open and closed), ${ }^{47,48}$ dynamic functional control was assessed with dynamic single limb balance test, double leg squat test (bubble goniometer was used to measure tibial and femoral angles), ${ }^{49,50}$ and the lateral step-down test. ${ }^{51}$

ROM was measured with a universal goniometer in supine for hip flexion, and in both supine (hip flexed to 90 degrees) and prone (0 degrees hip 
Table 1. Description of treatment algorithm used in the study.

Examination and Evaluation Components

Component One-

Medical Screening

Appropriate for PT evaluation and $\quad$ Appropriate for PT evaluation and intervention

intervention with consultation of another medical provider

Not appropriate for PT evaluation $\&$ intervention requiring consultation with healthcare provider

Component Two-

Differential evaluation of clinical findings according to body function and the associated pathology

Intra-Articular Pathology Clinical Findings:
- Anterior hip or Groin
- Symptoms with hip flexion
- Positive FADIR test
$\circ>50 \%$ relief $\mathrm{w} /$ Intra-articular injection
- Imaging consistent with Femeroacetabular impingement and/or labral pathology

\section{Component Three-}

Diagnosis of tissue Irritability level and match with appropriate dosage of examination and interventions. Low: Low pain with activity (NPRS $<3 / 10$ ) relieved as fast as aggravated. Higher level activities aggravate. Low disability levels: IHOT-33 $>65 \%$

Moderate: Moderate pain (NPRS 4-7/10) that lingers longer than aggravation time. Moderate level activities aggravate. Moderate disability levels: IHOT-33 64-36\%

Severe: Significant pain (NPRS >8/10) and difficulty to relieve symptoms. Low level activities such as ADL's aggravate. High disability levels: IHOT-33 $<35 \%$

\section{Component Four-}

Interventions strategies to address clinical findings of restriction in joint, soft tissue, and/or pain

\section{Joint
Lack of Mobility \\ Interventions:}

Low to high grade joint

mobilizations (Accessory \&

Physiological)

- Lumbopelvic Rotation C/R \& thrust mobilization

- Long Axis Hip Traction/Thrust

- Lateral Distraction MWM

- AP Mobilization

- PA Mobilization

Self-Mobilizations:

- Anterior hip: $1 / 2$ Stand Hip extension mobilization

- Posterior hip: Seated or standing piriformis mobilization

- Medial hip: Prone Figure 4

Lack of Neuromuscular Control Interventions:

Kinesthetic awareness:

- $\quad 1 / 2$ kneeling balance EO wide to narrow stance $\rightarrow \mathrm{EC} \rightarrow$ Dynamic arm movements

- SL balance EO $\rightarrow E C \rightarrow$ Dynamic arm and leg movements $\rightarrow$ Star reach

$$
\text { Soft Tissue Pain }
$$

Lack of Extensibility

Interventions:

Instrumented assisted and hands on soft tissue mobilization to specific structures

- Posterior Lumbopelvic Complex

- Lateral Hip/Thigh Complex

- Anterior Hip/Thigh Complex

- Medial Hip/Thigh complex

Contract-relax AROM $\rightarrow$ stretching

- Anterior: $1 / 2$ Stand quad

- Posterior: Piriformis

- Lateral: Side lying Ober's

- Medial: Prone Figure 4

Self-Mobilizations:

- Foam rolling

- Self-massage

- Self-contract-relax stretching Lack of Neuromuscular Control Interventions:

Muscle Activation $\rightarrow$ Endurance $\rightarrow$

Strength $\rightarrow$ Power

- Therapist applied assistance $\rightarrow$ Resistance function

- Isometric $\rightarrow$ Eccentric $\rightarrow$ Concentric contractions
Interventions:

Therapeutic neuroscience education

PRICE principles

Joint Motion/Pain free movement

- $\quad$ PROM $\rightarrow$ AAROM $\rightarrow$ AROM

Low Grade soft tissue and joint mobilizations

- Same as previous

\section{Biopsychosocial}

Interventions:

Therapeutic Neuroscience

Education

- Patient specific

Neural desensitization:

- Neurodynamic gliders $\rightarrow$ tensioners 


\begin{tabular}{|c|c|c|}
\hline Lack of Neuromuscular Control & Lack of Neuromuscular Control & Biopsychosocial \\
\hline Interventions: & Interventions: & Interventions: \\
\hline $\begin{array}{l}\text { Functional Movement } \\
\text { DL hip hinge } \rightarrow \text { DL squat } \rightarrow \\
\text { Anterior step up/down } \rightarrow \text { SL } \\
\text { squat } \\
\text { DL Hip hinge } \rightarrow \text { SL hip hinge } \rightarrow \\
\text { SL step back } \rightarrow \text { SL slider } \\
\text { Posterior lunge } \rightarrow \text { Posterior } \\
\text { lunge }\end{array}$ & $\begin{array}{l}\text { Transverse Plane: Hip IR/ER } \\
\text { MWM pain free hip ROM } \rightarrow \\
\text { Supine hip multi-angle } \\
\text { isometrics } \rightarrow \text { Side lying hip } \\
\text { IR/ER at } 0^{\circ} \& 90^{\circ} \rightarrow \text { Standing } \\
\text { Hip IR/ER on stool } \rightarrow \text { SL } \\
\text { balance hip IR/ER } \\
\text { Sagittal Plane } \\
\text { Prone hip extension } \rightarrow \\
\text { Bridging } \rightarrow 1 / 2 \text { stand hip ext. } \\
\text { Frontal Plane } \\
\text { Side lying hip abduction } \rightarrow \text { SL } \\
\text { balance with knee at } 0^{\circ}, 30^{\circ}, \\
\text { \& } 60^{\circ} \rightarrow \text { SL balance with hip } \\
\text { abduction } \rightarrow \text { Side stepping } \rightarrow \\
\text { Lateral lunges }\end{array}$ & $\begin{array}{l}\text { Graded exercises and activities } \\
\text { - } \quad \text { Patient specific }\end{array}$ \\
\hline \multicolumn{3}{|c|}{$\begin{array}{l}\text { PT - Physical Therapy; NPRS - Numeric Pain Rating Scale; IHOT-33 - International Hip Outcome Tool - 33; } \\
\text { ADLS - Activities of Daily Living; C/R - Contract Relax; MWM - Mobilization With Movement; AP - Anterior to } \\
\text { Posterior; PA - Posterior to Anterior; PRICE - Protections, Rest, Ice, Compression and Elevation; PROM - } \\
\text { Passive Range of Motion; AAROM - Active Assisted Range of Motion; AROM - Active Range of Motion; EO - } \\
\text { Eyes Open; EC - Eyes Closed; DL - Double Limb; SL - Single Limb; IR - Internal Rotation; ER - External Rotation }\end{array}$} \\
\hline
\end{tabular}

flexion) for hip internal rotation (IR) and external rotation (ER). Hip extension was estimated visually using a categorical scale of less than 0 degrees, less than 15 degrees, and greater than 15 degrees. ${ }^{52}$ Hip abduction, IR and ER strength were assessed, dependent on symptom irritability, using a handheld dynamometer (MicroFET2, Hoggan Health Industries, Salt Lake City, UT). The average of three trials was recorded. Positioning for abduction was in sidelying, and IR and ER in sitting. ${ }^{53}$ Muscle length and flexibility assessment included Ely's, modified Ober's, Thomas, piriformis, and FABER tests, ${ }^{21,52}$ which were scored as either positive or negative. A positive test was defined as asymmetry compared to the contralateral side or reproduction of comparable symptoms. ${ }^{2}$ Finally, joint provocation testing (FADIR, Scour, and log roll) were performed only when symptoms were not exacerbated during single plane ROM or flexibility testing. If symptoms were already provoked during single plane ROM or flexibility testing, it was reasoned that provocative tests would also replicate symptoms. As these tests demonstrate higher sensitivity than specificity, further provocation would have added no additional diagnostic information. ${ }^{2,54}$

\section{Clinical Reasoning for Categorization and Treatment Components}

By considering individual impairments and movement dysfunctions, treatment selection was matched to classification along the continuum. This allowed prioritization of interventions directed at mobility or neuromuscular control components, while simultaneously considering joint, soft tissue, or pain as primary contributors to the subjects' movement dysfunction. The fundamental component guiding examination and interventions was tissue irritability and its relationship to movement barriers (joint, soft tissue, or pain). ${ }^{55,56}$ Irritability has been previously described as the real time pain response, determined by the intensity of a physical activity required to produce comparable symptoms, and then the amount of time elapsed before those symptoms resolve. ${ }^{55,56}$ For these subjects, pain was not the only component of irritability but consideration was also given to how tissue irritability might impair muscle function and/or kinesthetic awareness during functional movement. Multiple subjective factors were considered when determining the level of irritability, including the subjective examination and selfreported outcome scores. Furthermore, irritability 


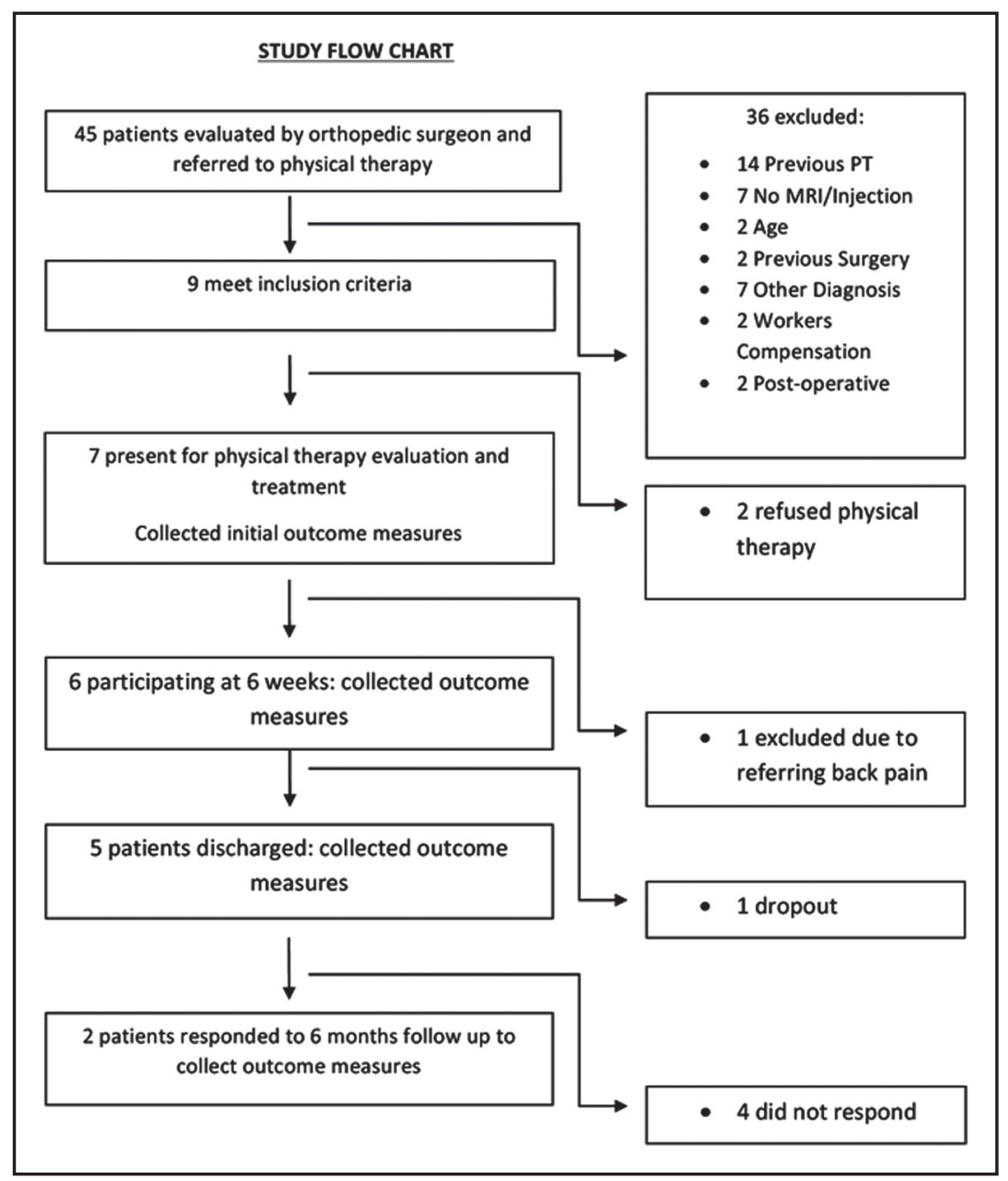

Figure 2. Study Flow Chart

Abbreviations: PT - Physical Therapy

\begin{tabular}{|ll|}
\hline Table 2. Demographic data. & \\
\hline Gender (\# Female/total sample) & $5 / 6$ \\
Age (years) & $37.8 \pm 15.4$ \\
Body mass index (kg/m ${ }^{2)}$ & $23.2 \pm 6.86$ \\
Duration of current episode (months) & $26.0 \pm 23.6$ \\
Symptom factors (positive results/total sample) & \\
Clicking/popping & $2 / 6$ \\
Pain with twisting & $2 / 6$ \\
Pain with adduction & $3 / 6$ \\
Pain with internal rotation & $3 / 6$ \\
Pain with flexion & $5 / 6$ \\
Imaging (positive results/total sample) & $3 / 6$ \\
CAM morphology & $2 / 6$ \\
Pincer morphology & $2 / 6$ \\
$\quad$ Labral tear & \\
\hline Age, Body mass index, duration of current episode, and prior episodes of hip pain are presented as \\
mean values \pm standard deviation.
\end{tabular}

guided the vigor of the objective examination, and was continually refined based upon the patient's response to the physical examination. For example, if irritability was low, and active ROM (AROM) was relatively asymptomatic, then joint overpressure was applied in order to ascertain the qualitative barrier to movement, such as soft tissue or joint. However, if irritability was high, and AROM reproduced 


\section{Table 3. Descriptions of outcome measures used in the current study.}

Outcome Measure
Medical Screening
Questionnaire
(MSQ)
International Hip
Outcome Tool - 33
(iHOT-33)

(iHOT-3

Numeric Pain Rating
Scale (NPRS)

Pain Catastrophizing

Scale (PCS)

Pain Diagram

Global Rating of

Change (GROC)
Patient Specific
Functional Scale
(PSFS)

Includes questions to explore medical problems that may pose a contraindication to treatment or medical referral.

Designed for young or active patients with hip pathology, consists of four sections including: symptoms and functional limitations, sports function and recreational activities, job related concerns, and social, emotional and lifestyle concerns. The 33 questions each use a visual analog scale to quantify the individuals function where the highest score of 100 represents full function.

Utilized to quantify subjective pain intensity. A 0-10 numeric pain rating scale (' 0 ' indicating no pain, and '10' worst imaginable pain).

Measures the extent to which people catastrophize in response to pain. 13-item patient-report scale, with three sub-scales (rumination, magnification and helplessness), each item is scored from 0 ('not at all') to 4 ('all the time'). Higher scores indicating greater catastrophizing.

A body diagram will be completed to identify the location and nature of symptoms.

The GROC questionnaire is utilized to assess short term changes in quality of life. The GROC has a 15-point scale with high scores representing greater improvement in a patient's perception of quality of life.

The PSFS was used to quantify subjective improvements in the patient's functional goals. Validation of this tool has not been specifically performed for the hip, however, validity and reliability has been demonstrated in musculoskeletal conditions such as the knee, lumbar spine, and cervical spine.
Psychometric Properties

None

Construct validity (correlation coefficient $=0.81$ )

Reliability (ICC $=0.78$,

Cronbach $\alpha=.99$ )

MCID 6.1 points

Test-retest reliability

MCID 2 points

Internal consistency and Construct validity

MDC 9.1 points

None

MCID more than 3 points

MCID 2.3 points symptoms, then overpressure was not applied, and ROM was deemed limited by pain. Similarly, if pain was elicited with muscle activation, formal strength testing was not performed.

As previously mentioned, the vigor of examination was matched with symptom provocation and irritability. The key elements guiding the decision to progress or hold on further objective testing were as follows:

- Movement Assessment: Individuals with a symptomatic double limb squat, who then failed single leg balance tests, were not asked to perform a lateral step-down test.

- Rationale: With the inability to perform double limb dynamic squat task without pain, and insufficient control with static single limb task, it is highly unlikely the prerequisite neuromuscular control for a single leg dynamic task was present.

- ROM assessment: If passive single plane ROM reproduced symptoms, then multi-plane assessment and provocative tests were not performed 
Table 4. Individual subject presentations along a continuum of neuromuscular control and mobility impairments.

Mobility

\begin{tabular}{|c|c|c|c|c|c|c|}
\hline Description & Mobility Patient 1 & Mobility Patient 2 & Mobility Patient 3 & $\begin{array}{c}\text { Neuromotor } \\
\text { Control Patient } 3\end{array}$ & $\begin{array}{c}\text { Neuromotor } \\
\text { Control Patient } 2\end{array}$ & $\begin{array}{c}\text { Neuromotor } \\
\text { Control Patient } 1\end{array}$ \\
\hline $\begin{array}{l}\dagger \text { Irritability } \\
\text { Level: }\end{array}$ & Moderate to low & Low & Low-Moderate & Moderate & Low & Low \\
\hline Pain & $\begin{array}{c}0 / 10 \text { at rest } \\
6 / 10 \text { with activities }\end{array}$ & $\begin{array}{c}0 / 10 \text { at rest } \\
3 / 10 \text { with activities }\end{array}$ & $\begin{array}{c}0 / 10 \text { at rest } \\
4 / 10 \text { with activities }\end{array}$ & $\begin{array}{c}1 / 10 \text { at rest } \\
7 / 10 \text { with activities }\end{array}$ & $\begin{array}{c}0 / 10 \text { at rest } \\
3 / 10 \text { with activates }\end{array}$ & $\begin{array}{c}0 / 10 \text { at rest } \\
4 / 10 \text { with activities }\end{array}$ \\
\hline $\begin{array}{l}\text { Outcome } \\
\text { Measures }\end{array}$ & $\begin{array}{l}\text { IHOT-33: } 54 \% \\
\text { PSFS: } 4 / 10\end{array}$ & $\begin{array}{l}\text { IHOT-33: } 32 \% \\
\text { PSFS: } 7 / 10\end{array}$ & $\begin{array}{l}\text { IHOT-33: } 41 \% \\
\text { PSFS: } 2 / 10\end{array}$ & $\begin{array}{c}\text { IHOT-33: } 46 \% \\
\text { PSFS: } 5.7 / 10\end{array}$ & $\begin{array}{l}\text { IHOT-33: } 65 \% \\
\text { PSFS: } 3.6 / 10\end{array}$ & $\begin{array}{l}\text { IHOT-33: } 73 \% \\
\text { PSFS: } 5.6 / 10\end{array}$ \\
\hline \multicolumn{7}{|c|}{ Lumbar Clearing } \\
\hline $\begin{array}{l}\text { - Flexion } \\
\text { - Extension } \\
\text { - Rotation }\end{array}$ & $\begin{array}{l}\text { Unremarkable } \\
\text { examination }\end{array}$ & $\begin{array}{l}\text { Unremarkable } \\
\text { examination }\end{array}$ & $\begin{array}{l}\text { *Restricted mulit- } \\
\text { segmental flexion } \\
\text { with inability to } \\
\text { touch toes }\end{array}$ & $\begin{array}{l}{ }^{*} \text { Excessive motion } \\
\text { with multi-segmental } \\
\text { flexion }\end{array}$ & $\begin{array}{c}\text { *Aberrant } \\
\text { movement with } \\
\text { multi-segmental } \\
\text { extension }\end{array}$ & $\begin{array}{l}\text { * Multiple movement } \\
\text { abnormalities in } \\
\text { multi-segmental } \\
\text { extension \& rotation }\end{array}$ \\
\hline
\end{tabular}

\begin{tabular}{|c|c|c|c|c|c|c|}
\hline & & & & & & \\
\hline \multicolumn{7}{|c|}{ Kinesthetic Awareness } \\
\hline $\begin{array}{l}\text {-Single leg } \\
\text { balance EO }\end{array}$ & $>30$ seconds & $>30$ seconds & $>30$ seconds & $>30$ seconds & $>30$ seconds & $>30$ seconds \\
\hline $\begin{array}{l}\text {-Single Leg } \\
\text { balance EC }\end{array}$ & $>30$ seconds & $*<10$ seconds & $*<10$ seconds & $*<10$ seconds & $>30$ seconds & $*<10$ seconds \\
\hline $\begin{array}{l}\text {-Dynamic } \\
\text { balance }\end{array}$ & $>30$ seconds & *Unable & *Unsteady & *Unsteady & *Unsteady & *Unsteady \\
\hline \multicolumn{7}{|c|}{ Functional Assessment } \\
\hline -Squat test & $\begin{array}{l}*-25^{\circ} \text { tibial angle } \\
-90^{\circ} \text { femoral angle }\end{array}$ & Full pain free squat & $\begin{array}{l}*-25^{\circ} \text { tibial angle } \\
-110^{\circ} \text { femoral angle }\end{array}$ & $\begin{array}{l}*-2^{\circ} \text { tibial angle } \\
-40^{\circ} \text { femoral angle }\end{array}$ & Full pain free squat & Full pain free squa \\
\hline $\begin{array}{l}\text { Lateral Step- } \\
\text { Down Score }\end{array}$ & $\begin{array}{c}\text { *Involved: } 4 / 6 \\
\text { Uninvolved: } 1 / 6\end{array}$ & Not tested & $\begin{array}{l}\text { *Involved: } 5 / 6 \\
\text { Uninvolved: } 4 / 6\end{array}$ & $\begin{array}{l}* \text { Involved: } 5 / 6 \\
\text { Uninvolved: } 5 / 6\end{array}$ & $\begin{array}{l}\text { *Involved: } 3 / 6 \\
\text { Uninvolved: } 0 / 6\end{array}$ & $\begin{array}{l}\text { *Involved: } 4 / 6 \\
\text { Uninvolved: } 4 / 6\end{array}$ \\
\hline
\end{tabular}

\begin{tabular}{|c|c|c|c|c|c|c|c|c|c|c|c|c|}
\hline Down Score & \multicolumn{2}{|c|}{ Uninvolved: $1 / 6$} & & & \multicolumn{2}{|c|}{ Uninvolved: $4 / 6$} & \multicolumn{2}{|c|}{ Uninvolved: $5 / 6$} & \multicolumn{2}{|c|}{ Uninvolved: $0 / 6$} & \multicolumn{2}{|c|}{ Uninvolved: $4 / 6$} \\
\hline \multicolumn{13}{|c|}{ Hip Range of Motion (degrees) } \\
\hline -Flexion & $\begin{array}{l}\text { Inv. } \\
* 105\end{array}$ & $\begin{array}{c}\text { Uninvolved } \\
120\end{array}$ & $\begin{array}{l}\text { Inv. } \\
* 110\end{array}$ & $\begin{array}{c}\text { Uninvolved } \\
120\end{array}$ & $\begin{array}{l}\text { Inv. } \\
130\end{array}$ & $\begin{array}{c}\text { Uninvolved } \\
130\end{array}$ & $\begin{array}{l}\text { Inv. } \\
* 105\end{array}$ & $\begin{array}{c}\text { Uninvolved } \\
110\end{array}$ & $\begin{array}{l}\text { Inv. } \\
140\end{array}$ & $\begin{array}{c}\text { Uninvolved } \\
140\end{array}$ & $\begin{array}{l}\text { Inv. } \\
130\end{array}$ & $\begin{array}{c}\text { Uninvolve } \\
130\end{array}$ \\
\hline $\begin{array}{l}-I R \text { at } 90^{\circ} \text { hip } \\
\text { flexion }\end{array}$ & $* 15$ & 45 & $* 48$ & 55 & 48 & 50 & 42 & 40 & 55 & 50 & 45 & 45 \\
\hline $\begin{array}{c}\text {-ER at } 90^{\circ} \text { hip } \\
\text { flexion }\end{array}$ & $* 50$ & 60 & $* 38$ & 45 & $* 47$ & 72 & $* 70$ & 55 & $* 45$ & 60 & 65 & 65 \\
\hline$-\operatorname{IR~} 0^{\circ}$ & $* 15$ & 40 & $* 35$ & 40 & 60 & 60 & 42 & 40 & $* 60$ & 55 & full & full \\
\hline$-\mathbf{E R} 0^{\circ}$ & 55 & 50 & 40 & 40 & $* 30$ & 55 & 45 & 50 & $* 40$ & 55 & full & full \\
\hline
\end{tabular}

\begin{tabular}{|c|c|c|c|c|c|c|}
\hline \multicolumn{7}{|c|}{ Flexibility Testing } \\
\hline $\begin{array}{l}\text { Anterior } \\
\text {-Ely's \& } \\
\text { Thomas }\end{array}$ & $\begin{array}{l}\text { Pain-free \& equal } \\
\text { limitation }\end{array}$ & $\begin{array}{l}\text { *Pain \& limited with } \\
\text { Ely's testing }\end{array}$ & $\begin{array}{l}\text { Pain-free \& equal } \\
\text { limitation }\end{array}$ & $\begin{array}{l}\text { Ely's non-painful \& } \\
\text { limited. *Thomas } \\
\text { painful \& limited }\end{array}$ & Pain-free \& limited & Normal \\
\hline $\begin{array}{l}\text { Lateral } \\
\text {-Ober's Test }\end{array}$ & $\begin{array}{l}\text { Pain-free \& equal } \\
\text { limitation }\end{array}$ & $\begin{array}{l}\text { Not tested due to + } \\
\text { Ely's test }\end{array}$ & $\begin{array}{l}\text { Pain-free \& equal } \\
\text { limitation }\end{array}$ & Pain-free \& limited & *Painful \& limited & Normal \\
\hline $\begin{array}{l}\text { Posterior } \\
\text {-Piriformis test }\end{array}$ & $\begin{array}{l}\text { Not tested due to } \\
\text { pain w/ isolated } \\
\text { flexion \& IR/ mod } \\
\text { irritability }\end{array}$ & Normal & *Painful \& limited & Pain-free \& limited & *Painful \& limited & *Painful \& limited \\
\hline $\begin{array}{l}\text { Medial Hip } \\
\text {-FABER test }\end{array}$ & $\begin{array}{l}\text { Not tested due to } \\
\text { limited hip ER at } 90^{\circ} \\
\text { already }\end{array}$ & $\begin{array}{l}\text { Not tested due to } \\
\text { limited hip ER at } 90^{\circ} \\
\text { already }\end{array}$ & $\begin{array}{l}\text { *Pain with excessive } \\
\text { motion }\end{array}$ & *Painful \& limited & $\begin{array}{l}\text { Not tested due to } \\
\text { limited hip ER at } \\
990^{\circ}\end{array}$ & $\begin{array}{l}\text { Non-painful \& } \\
\text { bilateral limitation }\end{array}$ \\
\hline $\begin{array}{l}\text { Hand Held } \\
\text { Dynamometer }\end{array}$ & $\begin{array}{l}\text { Mild weakness in } \\
\text { abduction }\end{array}$ & $\begin{array}{l}\text { Weakness in IR, ER } \\
\& \text { hip abduction }\end{array}$ & Weakness in IR & $\begin{array}{l}\text { Asymptomatic \& } \\
\text { symmetric }\end{array}$ & $\begin{array}{l}\text { Symmetric \& pain } \\
\text { free }\end{array}$ & $\begin{array}{l}\text { Not tested due to } \\
\text { pain with activation }\end{array}$ \\
\hline Imaging & $\begin{array}{c}\text { Mixed CAM \& } \\
\text { pincer impingement }\end{array}$ & $\begin{array}{c}\text { Mixed CAM \& } \\
\text { pincer impingement } \\
\text { with a small anterior } \\
\text { labral tear }\end{array}$ & Pincer impingement & CAM deformity & $\begin{array}{l}\text { CAM deformity \& } \\
\text { anterior labral tear }\end{array}$ & $\begin{array}{c}\text { Several cystic } \\
\text { changes resembling } \\
\text { a CAM deformity }\end{array}$ \\
\hline $\begin{array}{l}\text { Intervention } \\
\text { focus } \\
\text {-All patients } \\
\text { progressed to } \\
\text { functional } \\
\text { activity }\end{array}$ & $\begin{array}{l}\text {-Global Moderate to } \\
\text { high grade joint } \\
\text { mobilizations } \\
\text { - Frontal plane hip } \\
\text { strengthening }\end{array}$ & $\begin{array}{l}\text {-Anterior \& medial } \\
\text { Moderate to high } \\
\text { grade joint } \\
\text { mobilizations } \\
\text {-Soft tissue } \\
\text { mobilizations to } \\
\text { anterior-medial hip } \\
\text {-Kinesthetic } \\
\text { activities } \\
\text {-Transverse and } \\
\text { Frontal plane muscle } \\
\text { re-education }\end{array}$ & $\begin{array}{l}\text {-Posterior Moderate } \\
\text { to high grade joint } \\
\text { mobilizations } \\
\text {-Soft tissue } \\
\text { mobilizations to } \\
\text { posterior hip } \\
\text {-Kinesthetic } \\
\text { activities } \\
\text {-Transverse plane } \\
\text { muscle re-education }\end{array}$ & $\begin{array}{l}\text {-Soft tissue } \\
\text { techniques to anterior } \\
\text { hip/thigh } \\
\text {-Kinesthetic } \\
\text { awareness } \\
\text {-Transverse plane re- } \\
\text { education using } \\
\text { Mobilization with } \\
\text { movement mobs and } \\
\text { exercise for pain-free } \\
\text { activation }\end{array}$ & $\begin{array}{l}\text {-Soft tissue } \\
\text { techniques to } \\
\text { posterior hip/thigh } \\
\text {-Kinesthetic } \\
\text { awareness } \\
\text {-Transverse plane re- } \\
\text { education using } \\
\text { Mobilization with } \\
\text { movement mobs and } \\
\text { exercise for } \\
\text { endurance. }\end{array}$ & $\begin{array}{l}\text {-Kinesthetic } \\
\text { awareness } \\
\text {-Transverse plane re- } \\
\text { education using } \\
\text { Mobilization with } \\
\text { movement mobs and } \\
\text { exercise } \\
\text {-Required further } \\
\text { progression to power } \\
\text { activities }\end{array}$ \\
\hline \multicolumn{7}{|c|}{$\begin{array}{l}\text { Irritability Level: } \\
\text { Low: Low pain with activity (NPRS }<3 / 10 \text { ) relieved as fast as aggravated. Higher level activities aggravate. Low disability levels: IHOT-33>65\% } \\
\text { Moderate: Moderate pain (NPRS 4-7/10) that lingers longer than aggravation time. Moderate level activities aggravate. Moderate disability levels: IHOT-33 } 64-36 \% \\
\text { Severe: Significant pain }(\text { NPRS }>8 / 10 \text { ) and difficulty to relieve symptoms. Low level activities such as ADL's aggravate- High disability levels: IHOT- } 33>35 \%\end{array}$} \\
\hline
\end{tabular}

The International Journal of Sports Physical Therapy | Volume 13, Number 6 | December 2018 | Page 1039 
o Rationale: Increasing PROM into multiple planes increases tissue strain and the potential for further aggravation of symptoms without providing additional information. Moreover, in order to optimize treatment, aggravation of symptoms was minimized. Provocative tests of the hip include multiplane joint assessments as demonstrated by the FADIR (Flexion, Adduction and IR planes), Scour (Dynamic overpressure applied to FADIR positioning) and FABER (Flexion, Abduction, and ER).

- Flexibility Testing: If Ely's test in prone (assessing predominately anterior hip and thigh structures) was positive, a progression to Thomas and modified Ober's tests were not performed.

- Rationale: The progression to Thomas would be the same as with Ely's, with the addition of hip extension, to further stress anterior hip and thigh structures. Similarly, modified Ober's test includes the components of Thomas and then further stresses the structures of the lateral thigh with adduction.

- Strength assessment: If AROM was provocative formal strength assessment was not performed.

- Rationale: If symptoms were provoked with gravity dependent AROM then additional resistance is not indicated as this would potentially invalidate further strength assessment.

As the examination was guided by the level of symptom irritability, the clinician would simultaneously distinguish the foremost limiting factor for normal movement as either joint, soft tissue, or pain. For ROM, this was achieved by appreciating reproduction of symptoms and the qualitative barrier to movement with passive overpressure. For example, a hard, bony, end feel with overpressure was associated with potential alterations in joint morphology. Additionally, if the quality was more compliant and elastic, soft tissue (muscular or capsular) was reasoned to be the limiting factor. Interventions could include mobilizations or stretching for joint and soft tissue respectively. On the contrary, pain was considered the primary restriction to movement if symptoms limited the ability to reach an end feel.
Limitations due to pain would be treated with AROM exercises and gentle joint mobilizations (grade I - II) for pain modulation. Both nociceptive and biopsychosocial inputs were recognized as influential on the pain presentation. Skilled interventions require the recognition of all contributing biomedical and biopsychosocial components, discussion of which is beyond the scope of this paper. However, a recent study suggested examining five relevant "drivers" of pain to appropriately direct treatments (nociceptive, nervous system dysfunction, comorbidity, cognitive-emotional, and contextual). ${ }^{57}$

Finally, comprehensive assessment of objective examination findings helped determine whether movement dysfunctions were predominately due to lack of mobility/tissue extensibility or a lack of neuromuscular control. For instance, if squat depth was limited by pain, but isolated joint ROM was full and asymptomatic, neuromotor control was considered the limiting factor and the movement dysfunction would be categorized under neuromuscular control. If the greatest number of impairments were related to ROM, subjects were placed on the mobility end of the continuum and treatment was prioritized to address those primary limitations. If during functional movement tasks, alterations were observed in dynamic control or postural stability, subjects were placed toward the neuromuscular control end of the continuum and treatment prioritized neuromuscular control. In individuals with elevated pain and high irritability, it may be difficult to determine best placement along the neuromuscular control or mobility spectrum. Thus, treatment of pain (whether primarily influenced by nociceptive input and/or psychosocial factors) was the first priority. Thus, continual reassessment was performed through plan of care, during each visit.

\section{CASE SERIES DESCRIPTION AND TREATMENT}

Three of the six subjects were classified with primary mobility limitations based upon interpretation of examination findings. Clinical presentation in these subjects suggested a primary mobility dysfunction, based on limited ROM either at the joint or limited extensibility of surrounding soft tissues, with contributing weakness and poor neuromuscular control. 
Similarly, three subjects had primarily neuromuscular control dysfunctions, based on aberrant lumbopelvic movement, impaired kinesthetic awareness and poor control with functional testing. Furthermore, these subjects presented with normal or even excessive joint ROM in most planes of movement. Despite relatively normal joint ROM, flexibility was variably limited, suggesting other structures in the lumbosacral region or extra-articular structures of the hip might be involved.

Treatment prioritization was then matched with patient categorization on the treatment continuum, as well as directing interventions towards the primary movement barrier being either joint, soft tissue or pain. The first goal of treatment was to restore pain free AROM followed by full PROM and overpressure in a single plane then moving to multiple planes. Treatment choice was determined by the therapist's appreciation of which structures were predominately influencing nociceptive input, as described above.

When predominant joint mobility restrictions were identified, joint mobilization and self-mobilizations techniques were utilized to address specific, directional impairments. The vigor of treatment was matched to the patient's tissue irritability. Low grade (I or II) mobilizations were implemented for pain reduction in subjects with higher tissue irritability, while high grade (III - V) mobilizations, to improve full pain free ROM, in those with lower tissue irritability. If the barrier to movement was soft tissue, techniques included both hands on and instrumented assisted soft tissue mobilizations and were complimented with contract-relax stretching in order to improve pain free soft tissue mobility.

In subjects with primary neuromuscular control deficits the initial goals were to restore normal kinesthetic awareness to the joint. If pain was provoked with mid to end range functional movements, and/ or isolated joint ROM was normal, yet, symptomatic with overpressure, then mobilizations with movement were utilized to gain full, pain free ROM. Exercise selection was determined by best matching the exercise to the patient and their ability to successfully complete the task without provoking lasting symptoms. Modification was made via patient positioning and visual assistance. Progression was then made to dynamic control and functional movements. If subjects were symptomatic with activities of daily living, such as sit to stand, education on activity modification was provided to alter/limit activities until asymptomatic. ${ }^{32}$ For example, using hands to assist with sit to stand, or to avoid sitting on low surfaces. When objective loss of strength was present, exercise selection was determined by a subject's ability to complete pain-free muscle specific contractions starting with isometric to eccentric then concentric. When indicated by pain-free strength testing and functional movement, progression to power and plyometric exercises were implemented. Tissue irritability was a guiding factor for appropriate selection, frequency, duration, and intensity of interventions. ${ }^{54,55,56}$

\section{OUTCOMES}

From initial visit to discharge, iHOT-33, NPRS, PSFS, and GROC all improved, exceeding the MCIDs (Table 5). This improvement correlated with changes noted in each patient's objective data at discharge. Single limb balance with eyes closed, dynamic single limb balance, and lateral step-down tests (consistent

\begin{tabular}{|c|c|c|c|}
\hline Outcome Measure & Initial & Discharge & Change* \\
\hline IHOT-33 & $51.88 \pm 19.3 \%$ & $83.16 \pm 17.2 \%$ & $\begin{array}{c}27.30 \% \\
\text { (64 points) }\end{array}$ \\
\hline PCS & $10 \pm 9.71$ & $2.6 \pm 2.51$ & 7.2 \\
\hline GROC & & & 5.8 \\
\hline \multicolumn{4}{|l|}{ NPRS } \\
\hline Current & $1.5 \pm 1.57$ & $0.2 \pm 0.44$ & $2.3^{*}$ \\
\hline Best & $1.6 \pm 2.23$ & $0 \pm 0$ & $3.5^{*}$ \\
\hline Worst & $4.6 \pm 3.39$ & $3 \pm 2.12$ & $2.6^{*}$ \\
\hline PSFS & $4.7 \pm 2.09$ & $8.5 \pm 0.83$ & 3.8 \\
\hline \multicolumn{4}{|l|}{ ROM (degrees) } \\
\hline Flexion & $122 \pm 16.0$ & $138 \pm 7.58$ & 16 \\
\hline IR at 90 degrees & $41.0 \pm 15.3$ & $50.0 \pm 13.2$ & 9 \\
\hline ER at 90 degrees & $55.4 \pm 11.3$ & $63.6 \pm 3.51$ & 8.2 \\
\hline IR at 0 degrees & $44.3 \pm 21.3$ & $53.8 \pm 12.5$ & 9.5 \\
\hline ER at 0 degrees & $42.5 \pm 10.4$ & $50.0 \pm 7.07$ & 7.5 \\
\hline \multicolumn{4}{|l|}{ Strength (Ibs) } \\
\hline IR & $21.7 \pm 6.15$ & $31.9 \pm 9.62$ & $47.2 \%$ \\
\hline ER & $19.5 \pm 7.92$ & $23.3 \pm 6.66$ & $19.7 \%$ \\
\hline Abduction & $27.3 \pm 6.08$ & $37.9 \pm 4.87$ & $38.7 \%$ \\
\hline \multicolumn{4}{|c|}{$\begin{array}{l}\text { IHOT - } 33 \text { - international hip outcome tool; PCS - pain catastrophizing } \\
\text { scale; GROC - global rating of change scale; NPRS - numeric pain rating } \\
\text { scale; ROM - range of motion; IR - internal rotation; ER - external } \\
\text { rotation. } \\
\text { *Change in pain scores excluded individuals whose pain was a } 0 \\
\text { initially and at discharge for any of the timeframes. }\end{array}$} \\
\hline
\end{tabular}


findings in the neuromuscular control impaired subjects) were all improved after treatment. By the final visit, all functional tests were symmetrical and did not reproduce symptoms. ROM and strength improved on the involved side in all directions. Finally, a two-year review of patient records indicated that no patient had elected surgical management during this time.

On average subjects improved over the course of 8.6 visits (range: 5 - 11 visits) and duration of 81.4 days (range: 68 - 91 days). Median healthcare costs associated with management of each patient was on $\$ 12,215$ US dollars. Median expenditure was as follows: diagnostic measures consisted of $65 \%$ of the overall costs, imaging accounted for $43 \%(\$ 5,199)$ and injection procedures accounted for $22 \%(\$ 2,685)$ of the total. Patient management including physical therapy was $18 \%$ of the total cost $(\$ 2,242)$, with other medical office visits including primary care appointments associated with the hip diagnoses were 7\% (\$863) of the total. Other expenses included durable medical equipment, labs and chiropractic visits, which were less than $1 \%$ of total cost for each subject.

\section{DISCUSSION}

This clinical reasoning model and proposed intervention algorithm demonstrated meaningful improvement in pain, functional impairments, and perceived improvement in all six subjects. This approach relies on appropriate identification and placement of patient specific movement dysfunctions on a continuum to appropriately match specific treatment. Interventions were then directed to relevant factors limiting movement (pain, joint or soft tissue) and guided by tissue irritability. Although surgical criteria vary, ${ }^{8,9}$ the subjects described were all considered surgical candidates by their managing surgeon. The improvements seen corroborate recent guidelines suggesting value with a a physical therapy first approach. ${ }^{1,13,20}$

The precise etiology of intra-articular pathology in FAIS is still unclear, although it appears to be multifactorial. ${ }^{2,3,7,15-17,26,29,31}$ Because of this, emphasis should be placed on individualized treatment. ${ }^{20}$ There are, however, some common factors underlying intra-articular disease processes that can be targeted with conservative interventions. Mobility and neuromuscular control components will be discussed individually. First, consideration will be given to the evidence-based framework for this proposed continuum. Next, examining how patient presentations (impairments and functional movements) varied along the continuum. Finally, relevance of imaging/medical components will be considered.

\section{MOBILITY}

Abnormal joint mobility can contribute to symptoms. ${ }^{15,26,27,58}$ This could be due to congenital factors, microtrauma or macrotrauma, ${ }^{2,29}$ or an interactive process involving alterations in both mobility and neuromuscular control. 15,16,30,59,60 Regardless, in subjects with imaging findings suggestive of FAIS/ALTs, abnormalities have been identified in sagittal, frontal and transverse plane ROM in those with symptoms compared to asymptomatic. ${ }^{3,20,26,27,58}$ Alterations in joint ROM and muscular recruitment patterns can ultimately lead to concentrated areas of abnormal stress along the capsuloligamentous and articular structures. ${ }^{24,25,29,61-63}$ Likewise, excessive joint mobility can lead to aberrant loading of joint structures. ${ }^{17,24,29,30,59,60}$ These findings might imply that mobility restrictions have multiple etiologies and contributing components, which need to be prioritized and addressed specific to the unique needs of the patient.

The subjects in this case series demonstrated joint ROM abnormalities in at least one plane of motion. The three subjects with primary impairments of mobility presented with more global reduction in joint ROM, with varying degrees of severity. As ROM decreased, the need for neuromuscular control to compensate also decreased, leading to less difficulty controlling single leg functional and kinesthetic awareness tasks. This was seen most notably in the first patient categorized with a hypo-mobility dysfunction (Table 4). In contrast, the neuromuscular control subjects presented with more complex ROM abnormalities. One had increased joint ROM into flexion and ER, another had decreased flexion and increased ER, while the final exhibited a mixed pattern of hypermobility in flexion and IR, with limited ER. Isometric strength in the mobility subjects varied, with mild deficits in abduction for one, and more diffuse weakness on the involved side for another. Poor functional movement and neuromuscular 
control were a consistent finding in all subjects. The mobility subjects responded well to interventions targeting an increase in mobility with an eventual transition to neuromuscular control. Continual reassessment of the patient's impairments is important to monitor the change in patient's symptoms and continue to individualize treatment selection as they evolve over the course of care.

When considering symptomatic intra-articular dysfunctions, imaging should be put into context with information about joint mobility. It seems reasonable that imperfectly shaped joints may put individuals at risk for FAIS and ALTs, however, the presence of concomitant mobility dysfunctions may be necessary for symptom provocation. ${ }^{3,16,26,30,31,60,64}$ Two of the three subjects with primary impairments in hip mobility had imaging findings indicating elements of a mixed-type impingement. These morphological changes corroborated with the observed loss of ROM clinically. However, the third mobility patient had a pincer deformity which did not seem to align with the isolated ER ROM deficits observed clinically. Additionally, the patient with the greatest amount of mobility (considered hypermobile) had a cam deformity with a labral tear. These findings support prior evidence suggesting sole reliance on imaging is insufficient for valid identification of the nociceptive source. ${ }^{15}$ For example, radiographs demonstrating cam morphology combined with clinical loss of IR were more effective in predicting progression to OA than imaging alone. ${ }^{64}$ Furthermore, it was recently shown that lower mental health scores (Veterans RAND 12-item, mental component score) had a stronger association with symptoms than imaging in subjects with intra-articular pathology. ${ }^{65}$ Morphology should be considered but interpreted within the context of the clinical examination and patient presentation. It is possible that both a hypermobile and hypomobile joint will have underlying aberrant morphology and be at greater risk for producing symptoms. ${ }^{3,20,26,29,58}$

\section{NEUROMUSCULAR CONTROL}

Joint movement is inextricably linked to the surrounding muscle activity. ${ }^{15-17,24,26,59}$ Additionally, the neuromuscular system functions as a critical source of central nervous system input, where a tremendous amount of information is processed, including joint proprioceptive information which determines motor output. ${ }^{16,66-68}$ When articular structures are damaged, neuromuscular control needed to stabilize the joint may increase. ${ }^{2,29,30,69}$ Articular damage could be a result of microtrauma or macrotrauma, or could involve the components of joint hyper- or hypo-mobility dysfunctions previously discussed. 2,26,29,66 As joint damage occurs, the demand for muscular stability increases, while a concomitant reduction in neuromuscular control ensues as sensory input is altered. 2,29,30,66 Other factors may also be responsible for reductions in neuromuscular control such as effusion, pain inhibition, muscle weakness, and poor central processing. ${ }^{3,6,26,59,66,70-74}$ Furthermore, the long duration of symptoms before an appropriate diagnosis can increase the likelihood of developing neuromuscular control dysfunction, with evidence suggesting that central nervous system changes such as motor cortex re-organization are typical with persistent symptoms. ${ }^{59,65,66,75}$ Although surgical interventions can improve symptoms and morphology, functional impairments can persist 18 to 24 months or longer after arthroscopy. ${ }^{6}$ Unless the neuromuscular control dysfunction is addressed and movement patterns corrected, it is possible that symptoms may become persistent and recurrent. 3,16,17,20,22,24,26,30,58,59,66,72,76,77 Thus, individual symptoms could be primarily due to motor control dysfunctions, joint mobility dysfunctions, aberrant morphology, or perhaps are better conceptualized as an interactive combination of all three. ${ }^{59}$

Subjects in this case series consistently demonstrated poor neuromuscular control, with all but one having poor kinesthetic awareness with single limb balance eyes closed tests, and all having poor control with the lateral step-down test (Table 4). Aberrant movement identified with multi-segmental screening was common and was increasingly prominent the more the subject presented with neuromuscular control dysfunctions. Strength deficits varied in both groups. However, normal strength did not seem to determine normal functional movement, as symmetrical strength was observed in some subjects, despite asymmetrical functional movements. Although functional movement was improved by the final visit in most subjects, some deficits were still noted with many of 
the functional tasks. These differences were present despite improvements in ROM and strength, suggesting the presence of a complicated neuromuscular control dysfunction. The neuromuscular control subjects improved with interventions targeting muscle extensibility, muscle activation patterns, proprioceptive/kinesthetic training and eventual transition to more demanding functional neuromuscular control tasks. The question still remains as to whether welldeveloped movement interventions may prevent or assist in management of symptomatic intra-articular pathology long term.,20 Perhaps, treatment components should consider a spectrum of both mobility and neuromuscular control dysfunctions among individual subjects.

Although more difficult to conceptualize based on morphology alone, all subjects demonstrated improvements in function, pain, and movement control regardless of cam/pincer morphology or presence of ALTs. Perhaps the improvements in joint ROM, muscular strength and control of functional movements helped to slow the progression of intra-articular damage. One key argument for surgical intervention is to prevent the onset of osteoarthritis (OA).,10,78 However, exercise and joint movement can also slow down clinical progression of OA. ${ }^{8,12,64,71,78,79}$ If morphology predicts OA progression, yet OA responds well to conservative management, could FAIS also respond to conservative care $?^{80}$ A better understanding of effective non-surgical treatments is needed, and the approach described in this case series should be validated for effectiveness in larger scale prospective trials.

\section{NUMBER OF VISITS AND COST ANALYSIS}

With rising healthcare costs, it is relevant to ask if the proposed clinical reasoning and treatment continuum resulted in timely and cost-effective patient outcomes. Subjects improved on average over the course of 8.6 visits and 81.4 days, compared to five to 16 visits spanning 35 to 112 days in other reports. ${ }^{16-18,22,23,80,81}$ The median cost for each patient's physical therapy was $\$ 2,242$ in the present series. In contrast, this is far below the estimated $\$ 9,000$ a recent study predicted would be necessary for the definitive management of FAIS. ${ }^{10}$ Similarly, the entire mean cost of physical therapy care was less than the typical $\$ 2,456$ dollars required to make a diagnosis. ${ }^{5}$ With $65 \%$ of the costs being diagnostic in nature (i.e. imaging and diagnostic injection), perhaps physical therapy could be considered earlier in the treatment plan? Especially, as intra-articular injection is thought to have limited therapeutic benefit in isolation. ${ }^{82,83}$ Imaging and injections could potentially be postponed and utilized only if physical therapy management was unsuccessful.

\section{FUTURE DIRECTIONS}

Despite the large number of proposed contributors to intra-articular pathology, surgical management has been the predominating focus. ${ }^{7-9}$ Abnormal morphology provides a simple construct that lends itself well to the idea of surgical correction. ${ }^{15,17,19,26,29,31,69}$ However, the high prevalence of abnormal morphological findings in asymptomatic individuals suggests the problem is more complex. ${ }^{4,62,79,84-86}$ Similar patterns have been seen previously, aberrant shoulder and knee morphology lead to an exponential increase in invasive treatments which had not yet been established in the literature as more helpful than less invasive interventions. ${ }^{8,30}$ Therefore, providers must reason through how morphology, collectively with mobility and neuromuscular control impairments, can be addressed effectively with nonsurgical treatment approaches. ${ }^{16,17,26,29}$

The goal of this case series was to present an intervention program that is pragmatic, and easy to conceptualize and implement in clinical practice. While only one clinical trial comparing surgical to non-surgical interventions exists, ${ }^{87}$ the results remain inconclusive. Several other trials are due to be completed in the near future, and will likely provide more insight. ${ }^{1,9}$ Regardless, more research is needed to guide clinical decision making, and until then, current evidence suggests conservative management may be effective in treating individuals with intra-articular pathology and should occur prior to surgical interventions.

\section{LIMITATIONS}

The small sample size in this case series limits the generalizability and conclusiveness of the intervention approach utilized. Patient follow up was limited to two years, and only two out of the five discharged subjects directly responded to a request for a sixmonth follow up. Finally, it is possible the benefits 
may have been from a combination of therapy in addition to corticosteroid injection, or simply from the injection. However, evidence suggests injections are not long term solutions ${ }^{82,83}$ and unlikely to address the movement and control dysfunctions present in these subjects.

\section{CONCLUSIONS}

The etiology of symptomatic FAIS and ALTs is traditionally attributed to morphological abnormalities. However, based on the presence of these abnormalities in asymptomatic individuals, it appears the diagnosis and treatment of intra-articular pathology is more complicated. Treatment should focus on the individual patient, how their impairments may contribute to their symptoms and emphasize continual reassessment. Categorizing patients into initial treatment groups, based upon the proposed continuum of neuromuscular control and mobility deficits may help to facilitate treatment based clinical decision making.

\section{REFERENCES:}

1. Griffin D, Dickenson E, O'Donnell J, et al. The Warwick agreement on femoroacetabular impingement syndrome (FAI syndrome): an international consensus statement. Br J Sports Med. 2016;50(19):1169-1176.

2. Reiman M, Mather R, Hash T, Cook C. Examination of acetabular labral tear: a continued diagnostic challenge. Br J Sports Med. 2014;48(4):311-319.

3. Cheatham SW, Enseki KR, Kolber MJ. The clinical presentation of individuals with femoral acetabular impingement and labral tears: a narrative review of the evidence. J Bodyw Mov Ther. 2016;20(2):346-355.

4. Gerhardt M, Romero A, Silvers H, Harris D, Watanabe D, Mandelbaum B. The prevalence of radiographic hip abnormalities in elite soccer players. Am J Sports Med. 2012;40(3):584-588.

5. Kahlenberg C, Han B, Patel R, Deshmane P, Terry M. Time and cost of diagnosis for symptomatic femoroacetabular impingement. Orthop J Sports Med. 2014;2(3):2325967114523916.

6. Kemp JL, Risberg MA, Schache AG, Makdissi M, Pritchard MG, Crossley KM. Patients with chondrolabral pathology have bilateral functional impairments 12 to 24 months after unilateral hip arthroscopy: a cross-sectional study. J Orthop Sports Phys Ther. 2016;46(11):947-956.

7. Wall P, Fernandez M, Griffin D, Foster N. Nonoperative treatment for femoroacetabular impingement: a systematic review of the literature. PM R. 2013;5(5):418-426.

8. Reiman MP, Thorborg K. Femoroacetabular impingement surgery: are we moving too fast and too far beyond the evidence? Br J Sports Med. 2015;49:782-784.

9. Reiman MP, Thorborg K, Hölmich P. Femoroacetabular impingement surgery is on the rise-but what is the next step? J Orthop Sports Phys Ther. 2016;46(6):406-408.

10. Lodhia P, Gui C, Chandrasekaran S, Suarez-Ahedo C, Dirschl DR, Domb BG. Cost-effectiveness analysis of hip arthroscopic surgery and structured rehabilitation alone in individuals with hip labral tears: response. Am J Sports Med. 2017;45(3):NP2-NP4.

11. Bove AM, Clohisy J, DeWitt J, et al. Costeffectiveness analysis of hip arthroscopic surgery and structured rehabilitation alone in individuals with hip labral tears: letter to the editor. Am J Sports Med. 2017;45(3):NP1-NP2.

12. Wright AA, Hegedus EJ, Taylor JB, Dischiavi SL, Stubbs AJ. Non-operative management of femoroacetabular impingement: a prospective, randomized controlled clinical trial pilot study. J Sci Med Sport. 2016;19(9):716-721.

13. Reiman M, Thorborg K, Covington $\mathrm{K}$, Cook C, Hölmich P. Important clinical descriptors to include in the examination and assessment of patients with femoroacetabular impingement syndrome: an international and multi-disciplinary Delphi survey. Knee Surg Sports Traumatol Arthrosc. 2017:1-12.

14. Emara K, Samir W, Motasem E, Ghafar K. Conservative treatment for mild femoroacetabular impingement. J Orthop Surg Hong Kong. 2011;19(1):41-45.

15. Loudon J, Reiman M. Conservative management of femoroacetabular impingement (FAI) in the long distance runner. Phys Ther Sport. 2014;15(2):82-90.

16. Narveson J, Haberl M, Grabowski P. Management of a patient with acute acetabular labral tear and femoral acetabular Impingement with Intra-articular steroid Injection and a neuromotor training program. J Orthop Sports Phys Ther. 2016;46(11):965-975.

17. Yazbek P, Ovanessian V, Martin R, Fukuda T. Nonsurgical treatment of acetabular labrum tears: a case series. J Orthop Sports Phys Ther. 2011;41(5):346353.

18. Cashman G, Mortenson W, Gilbart M. Myofascial treatment for patients with acetabular labral tears: a single-subject research design study. J Orthop Sports Phys Ther. 2014;44(8):604-614. 
19. Orbell S, Smith T. The physiotherapeutic treatment of acetabular labral tears: A systematic review. Adv Physiother. 2011;13(4):153-161.

20. Theige M, David S. Nonsurgical treatment of acetabular labral tears. J Sport Rehabil. 2017; 27(4):380-384.

21. Enseki K, Harris-Hayes M, White DM, et al. Nonarthritic hip joint pain: clinical practice guidelines linked to the international classification of functioning, disability and health from the orthopaedic section of the American Physical Therapy Association. J Orthop Sports Phys Ther. 2014;44(6):A1-A32.

22. Macintyre K, Gomes B, MacKenzie S, D'Angelo K. Conservative management of an elite ice hockey goaltender with femoroacetabular impingement (FAI): a case report. J Can Chiropr Assoc. 2015;59(4):398.

23. LeBeau R, Nho S. The use of manual therapy posthip arthroscopy when an exercise-based therapy approach has failed: a case report. J Orthop Sports Phys Ther. 44(9):712-721.

24. Lewis CL, Sahrmann SA. Effect of posture on hip angles and moments during gait. Man Ther. 2015;20(1):176-182.

25. Samaan MA, Schwaiger BJ, Gallo MC, et al. Joint loading in the sagittal plane during gait is associated with hip joint abnormalities in patients with femoroacetabular impingement. Am J Sports Med. 2017;45(4):810-818.

26. Bagwell JJ, Snibbe J, Gerhardt M, Powers CM. Hip kinematics and kinetics in persons with and without cam femoroacetabular impingement during a deep squat task. Clin Biomech. 2016;31:87-92.

27. Lamontagne M, Kennedy MJ, Beaulé PE. The effect of cam FAI on hip and pelvic motion during maximum squat. Clin Orthop. 2009;467(3):645-650.

28. Kennedy MJ, Lamontagne M, Beaule PE. Femoroacetabular impingement alters hip and pelvic biomechanics during gait: walking biomechanics of FAI. Gait Posture. 2009;30(1):41-44.

29. Smith C, Masouros S, Hill A, Amis A, Bull A. A biomechanical basis for tears of the human acetabular labrum. Br J Sports Med. 2009;43(8):574578.

30. Martin RL, Enseki KR, Draovitch P, Trapuzzano T, Philippon MJ. Acetabular labral tears of the hip: examination and diagnostic challenges. J Orthop Sports Phys Ther. 2006;36(7):503-515.

31. Canham CD, Yen Y-M, Giordano BD. Does femoroacetabular impingement cause hip instability? A systematic review. Arthrosc J Arthrosc Relat Surg. 2016;32(1):203-208.
32. Harris-Hayes M, Czuppon S, Van Dillen LR, et al. Movement-pattern training to improve function in people with chronic hip joint pain: a feasibility randomized clinical trial. J Orthop Sports Phys Ther. 2016;46(6):452-461.

33. Mohtadi N, Griffin D, Pedersen M, et al. The development and validation of a self-administered quality-of-life outcome measure for young, active patients with symptomatic hip disease: the International Hip Outcome Tool (iHOT-33). Arthrosc J Arthrosc Relat Surg. 2012;28(5):595-610.

34. Chan C, Goldman S, Kunselman A, O'Neill P. The pain drawing and Waddell's nonorganic physical signs in chronic low-back pain. Spine. 1993;18(3):1717-1722.

35. Beattie P, Meyer S, Stratford P, Millard R, Hollenberg G. Associations between patient report of symptoms and anatomic impairment visible on lumbar magnetic resonance imaging. Spine. 2000;25(7):819828.

36. Jensen M, Turner J, Romano J. What is the maximum number of levels needed in pain intensity measurement? Pain. 1994;58(3):387-392.

37. Osman A, Barrios F, Kopper B, Hauptmann W, Jones J, O'Neill E. Factor structure, reliability, and validity of the Pain Catastrophizing Scale. J Behav Med. 1997;20(6):589-605.

38. Osman A, Barrios F, Gutierrez P, Kopper B, Merrifield T, Grittmann L. The Pain Catastrophizing Scale: further psychometric evaluation with adult samples. J Behav Med. 2000;23(4):351-365.

39. Jaeschke R, Singer J, Guyatt G. Measurement of health status: ascertaining the minimal clinically important difference. Control Clin Trials. 1989;10(4):407-415.

40. Juniper E, Guyatt G, Willan A, Griffith L. Determining a minimal important change in a disease-specific quality of life questionnaire. J Clin Epidem. 1994;47(1):81-87.

41. Fritz J, Irrgang J. A comparison of a modified Oswestry low back pain disability questionnaire and the Quebec back pain disability scale. Phys Ther. 2001;81(2):776-788.

42. Horn KK, Jennings S, Richardson G, Van Vliet D, Hefford C, Abbott JH. The patient-specific functional scale: psychometrics, clinimetrics, and application as a clinical outcome measure. J Orthop Sports Phys Ther. 2012;42(1):30-D17.

43. Majlesi J, Togay H, Ünalan H, Toprak S. The sensitivity and specificity of the Slump and the Straight Leg Raising tests in patients with lumbar disc herniation. J Clin Rheumatol. 2008;14(2):87-91. 
44. Walsh J, Hall T. Agreement and correlation between the straight leg raise and slump tests in subjects with leg pain. J Manipulative Physiol Ther. 2009;32(3):184192.

45. Laslett M, Aprill C, McDonald B, Young S. Diagnosis of sacroiliac joint pain: validity of individual provocation tests and composites of tests. Man Ther. 2005;10(3):207-218.

46. Cook C, Hegedus E. Orthopedic Physical Examination Tests: An Evidence-Based Approach. Higher. Pearson; 2012.

47. Riemann B, Myers J, Lephart S. Comparison of the ankle, knee, hip, and trunk corrective action shown during single-leg stance on firm, foam, and multiaxial surfaces. Phys Med Rehabil. 2003;84(1):90-95.

48. Kuo A, Speers R, Peterka R, Horak F. Effect of altered sensory conditions on multivariate descriptors of human postural sway. Exp Brain Res. 1998;122(2):185-195.

49. Kiesel K, Burton L, Cook G. Mobility screening for the core. Athl Ther Today. 2004;9(5):38-41.

50. Noda T, Verscheure S. Individual goniometric measurements correlated with observations of the deep overhead squat. Athl Train Sports Health Care. 2009;1(2):114-119.

51. Rabin A, Kozol Z. Measures of range of motion and strength among healthy women with differing quality of lower extremity movement during the lateral step-down test. J Orthop Sports Phys Ther. 2010;40(12):792-800.

52. Pua Y-H, Wrigley TW, Cowan SM, Bennell KL. Intrarater test-retest reliability of hip range of motion and hip muscle strength measurements in persons with hip osteoarthritis. Arch Phys Med Rehabil. 2008;89(6):1146-1154.

53. Thorborg K, Petersen J, Magnusson S, Hölmich P. Clinical assessment of hip strength using a handheld dynamometer is reliable. Scand J Med Sci Sports. 2010;20(3):493-501.

54. Maslowski E, Sullivan W, Harwood JF, et al. The diagnostic validity of hip provocation maneuvers to detect intra-articular hip pathology. PM $R$. 2010;2(3):174-181.

55. Barakatt ET, Romano PS, Riddle DL, Beckett LA, Kravitz R. An exploration of Maitland's concept of pain irritability in patients with low back pain. J Man Manip Ther. 2009;17(4):196-205.

56. Smart K, Doody C. The clinical reasoning of pain by experienced musculoskeletal physiotherapists. Man Ther. 2007;12(1):40-49.

57. Tousignant-Laflamme Y, Martel MO, Joshi AB, Cook CE. Rehabilitation management of low back pain-it's time to pull it all together! J Pain Res. 2017;10:23732385.

58. Azevedo DC, Paiva EB, Lopes AMA, et al. Pelvic rotation in femoroacetabular impingement is decreased compared to other symptomatic hip conditions. J Orthop Sports Phys Ther. 2016;46(11):957-964.

59. Harris-Hayes M, Mueller MJ, Sahrmann SA, et al. Persons with chronic hip joint pain exhibit reduced hip muscle strength. J Orthop Sports Phys Ther. 2014;44(11):890-898.

60. Kalisvaart MM, Safran MR. Microinstability of the hip-it does exist: etiology, diagnosis and treatment. J Hip Preserv Surg. 2015;2(2):123-135.

61. Hölmich P, Thorborg K, Nyvold P, Klit J, Nielsen MB, Troelsen A. Does bony hip morphology affect the outcome of treatment for patients with adductorrelated groin pain? Outcome 10 years after baseline assessment. Br J Sports Med. 2014;48:1240-1244.

62. Tresch F, Dietrich TJ, Pfirrmann CW, Sutter R. Hip MRI: prevalence of articular cartilage defects and labral tears in asymptomatic volunteers. A comparison with a matched population of patients with femoroacetabular impingement. J Magn Reson Imaging. 2017;46(2):440-51.

63. Samaan MA, Teng H-L, Kumar D, et al. Acetabular cartilage defects cause altered hip and knee joint coordination variability during gait. Clin Biomech. 2015;30(10):1202-1209.

64. Agricola R, Weinans H. Femoroacetabular impingement: what is its link with osteoarthritis? $\mathrm{Br}$ J Sports Med. 2015;50:957-958

65. Jacobs CA, Burnham JM, Jochimsen KN, Molina D, Hamilton D, Duncan ST. Preoperative symptoms in femoroacetabular impingement patients are more related to mental health scores than the severity of labral tear or magnitude of bony deformity. $J$ Arthroplasty. 2017;2(12):3603-3606

66. Röijezon U, Clark NC, Treleaven J. Proprioception in musculoskeletal rehabilitation. Part 1: Basic science and principles of assessment and clinical interventions. Man Ther. 2015;20(3):368-377.

67. Lephart S, Pincivero D, Giraido J, Fu F. The role of proprioception in the management and rehabilitation of athletic injuries. Am J Sports Med. 1997;25(1):130-137.

68. Proske U. What is the role of muscle receptors in proprioception? Muscle Nerve. 2005;31(6):780-787.

69. Safran MR, Giordano G, Lindsey DP, et al. Strains across the acetabular labrum during hip motion: a cadaveric model. Am J Sports Med. 2011;39(1_ supp1):92S-102S. 
70. Clark NC, Röijezon U, Treleaven J. Proprioception in musculoskeletal rehabilitation. Part 2: clinical assessment and intervention. Man Ther. 2015;20(3):378-387.

71. Kierkegaard S, Mechlenburg I, Lund B, Søballe K, Dalgas U. Impaired hip muscle strength in patients with femoroacetabular impingement syndrome. J Sci Med Sport. 2017;20(12):1062-1067.

72. Freeman S, Mascia A, McGill S. Arthrogenic neuromusculature inhibition: a foundational investigation of existence in the hip joint. Clin Biomech. 2013;28(2):171-177.

73. Nepple JJ, Goljan P, Briggs KK, Garvey SE, Ryan M, Philippon MJ. Hip strength deficits in patients with symptomatic femoroacetabular impingement and labral tears. Arthrosc J Arthrosc Relat Surg. 2015;31(11):2106-2111.

74. Puentedura EJ, Louw A. A neuroscience approach to managing athletes with low back pain. Phys Ther Sport. 2012;13(3):123-133.

75. Lotze M, Moseley GL. Role of distorted body image in pain. Curr Rheumatol Rep. 2007;9(6):488-496.

76. Mendis MD, Wilson SJ, Hayes DA, Watts MC, Hides JA. Hip flexor muscle size, strength and recruitment pattern in patients with acetabular labral tears compared to healthy controls. Man Ther. 2014;19(5):405-410.

77. Lewis CL, Sahrmann SA, Moran DW. Anterior hip joint force increases with hip extension, decreased gluteal force, or decreased iliopsoas force. J Biomech. 2007;40(16):3725-3731.

78. Fairley J, Wang Y, Teichtahl AJ, et al. Management options for femoroacetabular impingement: a systematic review of symptom and structural outcomes. Osteoarthritis Cartilage. 2016;24(10):16821696.

79. Jung K, Restrepo C, Hellman M, AbdelSalam H, Morrison W, Parvizi J. The prevalence of cam-type femoroacetabular deformity in asymptomatic adults. J Bone Jt Surg Br. 2011;93(10):1303-1307.
80. Wright A, Hegedus E. Augmented home exercise program for a 37-year-old female with a clinical presentation of femoroacetabular impingement. Man Ther. 2012;17(4):358-363.

81. Khoo-Summers L, Bloom NJ. Examination and treatment of a professional ballet dancer with a suspected acetabular labral tear: a case report. Man Ther. 2015;20(4):623-629.

82. Krych A, Griffith T, Kuzma S, Sierra R, Levy B. Limited therapeutic benefits of intra-articular cortisone injection for patients with femoroacetabular impingement and labral tear. Knee Surg Sports Traumatol Arthrosc. 2014;22(4):750-755.

83. Levy B, Griffith T, Krych A, Hudgens J, Sierra R. Intra-articular cortisone injection has limited clinical benefit for non-operative treatment of femoral acetabular impingement with labral pathology. Arthroscopy. 29(6):e14.

84. Silvis M, Mosher T, Smetana BS, et al. High prevalence of pelvic and hip magnetic resonance imaging findings in asymptomatic collegiate and professional hockey players. Am J Sports Med. 2011;39(4):715-721.

85. Gallo R, Silvis M, Smetana B, et al. Asymptomatic hip/groin pathology identified on magnetic resonance imaging of professional hockey players: outcomes and playing status at 4 years' follow-up. Arthrosc J Arthrosc Relat Surg. 2014;30(10):1222-1228.

86. Schmitz M, Campbell S, Fajardo R, Kadrmas W. Identification of acetabular labral pathological changes in asymptomatic volunteers using optimized, noncontrast 1.5-T magnetic resonance imaging. Am J Sports Med. 2012;40(6):1337-1341.

87. Mansell NS, Rhon DI, Meyer J, Slevin JM, Marchant BG. Arthroscopic surgery or physical therapy for patients with femoroacetabular impingement syndrome: a randomized controlled trial with 2-year follow-up. Am J Sports Med. 2018;46(6):1306-1314. 